Acta vet. scand. $1986,27,378-387$.

From the University of Illinois, Champaign-Urbana, USA and Ambulatory Clinic, College of Veterinary Medicine, Hautjärvi, Finland.

\title{
MORPHOLOGIG EVALUATION OF ACUTE ENDOMETRITIS IN MARES WITH DIFFERING RESISTANCE TO UTERINE INFECTIONS
}

\author{
By \\ T. Katila, T. F. Lock, R. W. Ely and A. R. Smith
}

\begin{abstract}
KATILA, T., T. F. LOCK, R. W. ELY and A. R. SMITH: Morphologic evaluation of acute endometritis in mares with differing resistance to uterine infections. Acta vet. scand. 1986, 27, 378-387. - The study was designed to determine differences between normal mares and mares with endometrial pathology in the inflammatory response after bacterial challenge. Six normal mares (biopsy category I) and 4 mares with pathological endometrial changes (biopsy category II) were given an intrauterine infusion of $\beta$-hemolytic streptococci on the second day of estrus. All mares had a similar kind of inflammatory response after the bacterial inoculation as assessed by rectal and vaginal examinations. There were no significant differences in the amount of discharge, uterine tone, uterine size and cervical relaxation between the groups. Leukocytic response, as determined by endometrial smears and biopsies, was of the same magnitude in both groups. Two mares from the pathological group were not able to eliminate the infection, but had vaginal discharge and bacteriologically positive uterine swabs until the end of the experiment. It is concluded that the inability of some mares to clear uterine infections cannot be explained by a deficient inflammatory response.
\end{abstract}

inflammation; $\beta$-hemolytic streptococci; leukocytes; uterine biopsy; uterine tone; uterine size; cervical relaxation.

Studies involving experimental infections have contributed to a better understanding of the response of the equine uterus to bacterial infections (Hughes \& Loy 1969, Peterson et al. 1969, Bowman 1972, Asbury et al. 1980, Washburn et al. 1982). The studies have shown that normal mares develop a rapid and strong inflammatory response after the bacterial inoculation. It is characterized by increased uterine tone and size, accumula- 
tion of exudate in uterine lumen and cervical relaxation. There has been some evidence that mares with decreased resistance to uterine infections would not respond in a similar way. A chronically infected mare, which received an intrauterine inoculation of Str. zooepidemicus, exhibited very little cervical or uterine reaction to the bacterial challenge as compared to a maiden mare (Hughes \& Loy 1969).

Peterson et al. (1969) studied endometrial biopsies and smears after intrauterine inoculation of bacteria. In their study 4 normal mares and 2 barren mares developed a similar kind of inflammatory response, but the barren mares required more than one estrous cycle to eliminate the bacteria, whereas the normal mares cleared the bacteria within 4 to 15 days post-exposure.

The purpose of the study was to test by means of clinical examinations and endometrial biopsies the hypothesis that mares with initial pathological changes in the endometrium would have no or a milder inflammatory response after bacterial challenge of the uterus as compared to normal mares.

\section{MATERIALS AND METHODS}

Ten mares of various ages ( $2-22$ years) and breeds were used in the study. The horses were kept on pasture until the experiment began. During the study, from June to October, they were housed inside and fed a diet of oats and alfalfa hay.

Endometrial biopsies were taken before the experiment began. Biopsies were categorized according to Kenney's classifications (Kenney 1978). Six mares with normal endometrial histology were assigned to biopsy category I (group I). Four mares had moderate pathological endometrial changes, and they were placed in biopsy category II (group II).

The mares were teased daily. On the 2nd day of estrus all mares were given an intrauterine infusion of $\beta$-hemolytic streptococci. The average ionculation dose was $3.5 \times 10^{9}$ colony forming units (CFU) in a total volume of $15 \mathrm{ml}$ of Todd Hewitt broth ${ }^{1}$. The schedule of examinations and samplings is presented in Table 1. Examinations included inspection of external genitalia, where the presence, consistency, and color of discharge from the vulva was noted. Also during vaginoscopy the amount and

1 Todd Hewitt Medium. BBL Microbiology Systems, Becton Dickinson and Co., Cockeysville, MD 21030, USA. 
Table 1. The timing of examinations and sampling. Hours after bacterial inoculation are indicated by " $h$ ", and " $d$ " means days after ovulation.

\begin{tabular}{|c|c|c|c|c|}
\hline Time & $\begin{array}{c}\text { Rectal } \\
\text { examination }\end{array}$ & $\begin{array}{c}\text { Vaginal } \\
\text { examination }\end{array}$ & $\begin{array}{c}\text { Uterine } \\
\text { swab }\end{array}$ & $\begin{array}{l}\text { Uterine } \\
\text { biopsy }\end{array}$ \\
\hline $0 \mathrm{~h}$ & $\mathbf{x}$ & $\mathbf{x}$ & $\mathbf{x}$ & \\
\hline $2 \mathrm{~h}$ & $\mathbf{x}$ & $\mathbf{x}$ & & \\
\hline $4 \mathrm{~h}$ & $\mathbf{x}$ & $\mathbf{x}$ & & \\
\hline $6 \mathrm{~h}$ & $\mathbf{x}$ & $\mathbf{x}$ & $\mathbf{x}$ & \\
\hline $12 \mathrm{~h}$ & $\mathbf{x}$ & $\mathbf{x}$ & $\mathbf{x}$ & $\mathbf{x}$ \\
\hline $24 \mathrm{~h}$ & $\mathbf{x}$ & $\mathbf{x}$ & $\mathbf{x}$ & \\
\hline $48 \mathrm{~h}$ & $\mathbf{x}$ & $\mathbf{x}$ & $\mathbf{x}$ & $\mathbf{x}$ \\
\hline $2 d$ & $\mathbf{x}$ & $\mathbf{x}$ & & \\
\hline $7 \mathrm{~d}$ & $\mathbf{x}$ & $\mathbf{x}$ & & \\
\hline $12 \mathrm{~d}$ & $\mathbf{x}$ & $\mathbf{x}$ & $\mathbf{x}$ & $\mathbf{x}$ \\
\hline
\end{tabular}

character of discharge was recorded. The color, degree of opening and the general appearance of the external cervical os was noted. Cervical tone was determined by rectal palpation. The uterus was carefully palpated paying special attention to its size and tone. The diameter of uterine horns was measured by encircling them between thumb and forefinger or middle finger as recommended by Greenhoff \& Kenney (1975).

Bacteriological cultures and cytological smears were obtained using a guarded culture swab $^{1}$. The same swab was used for bacteriology and cytology. The cultures were done first, by streaking a blood agar plate with the tip of the swab. The plates were incubated for $24 \mathrm{~h}$ at $37^{\circ} \mathrm{C}$. Cytological smears were obtained by rolling the side of the swab on a slide. The slide was air-dried and stained with a modified polychrome methylene blue stain using an automatic staining apparatus ${ }^{2}$.

Biopsies were taken from the left or right junction between the uterine body and horns (Kenney 1978) by an instrument with alligator-type jaws ${ }^{3}$. The biopsy specimens were fixed in Bouin's solution and transferred into $10 \%$ buffered neutral formalin after $24 \mathrm{~h}$. The fixed tissues were embedded in paraf-

1 Guarded Culture Instrument. Kalayjian Industries, Inc., 6050 Appaian Way, Long Beach, CA 90803, USA.

${ }^{2}$ Hema-tek Slide Stainer. Ames Division, Miles Laboratories, Inc., P. O. Box 70, Elkhart, IN 46515, USA.

3 Pilling Equine Endometrial Biopsy Punch. Pilling Surgical Instruments, Fort Washington, Pennsylvania, USA. 
fin, sectioned into $6 \mu \mathrm{m}$, and stained with hematoxylin and eosin. The principles described by Kenney were followed in the interpretation of the biopsies (Kenney 1978).

\section{RESULTS}

All mares responded to the inoculation with acute inflammation of the uteri. Most mares showed external signs $6-24 \mathrm{~h}$ after the inoculation. There was discharge exuding from the ventral commissure of the vulva. The vulva was often swollen, with inflamed mucosa externally visible. None of the mares showed any signs of discomfort, straining, or elevation of the tail. No changes in appetite or general appearance were noted.

On vaginal examination, hyperemia of vaginal walls and external cervical os was usually present at $2-48 \mathrm{~h}$. The external cervical os was edematous and dilated. Nine mares had a clear or grayish discharge in the vagina $2 \mathrm{~h}$ after the inoculation. All mares had a mucopurulent gray or yellow discharge in the

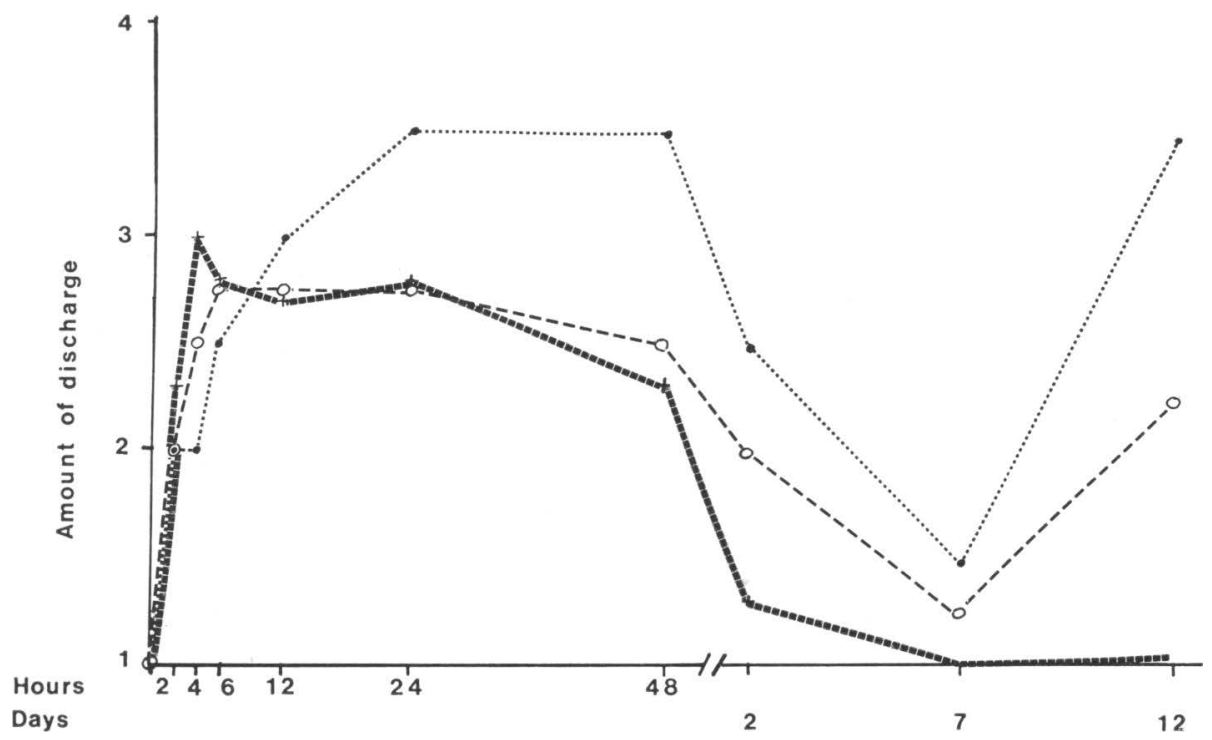

Fig u re 1. The amount of discharge after the bacterial inoculation. Means plotted on the $y$-axis have been calculated from values that were given in the following way: $1=$ no discharge, $2=$ very little discharge, $3=$ a significant amount of discharge, $4=$ a large amount of discharge pooling in vagina. Besides averages for group $I(x-x)$ and group II $(O \ldots .-))$, the mares from group II that remained infected are shown separately $(0 \ldots . .0)$. 
vagina at $4 \mathrm{~h}$. Two mares from group II, which were not able to eliminate the bacterial infection, tended to have less discharge at $4 \mathrm{~h}$. They continued to have discharge for several weeks, whereas other mares had no discharge on the 7 th day after ovulation (Fig. 1).

Cervical relaxation as assessed by rectal palpation occurred within $2 \mathrm{~h}$ after the inoculation. The relaxation followed approximately the same pattern in both groups. The cervical tone began to increase after $48 \mathrm{~h}$ (Fig. 2).

The uterine horn diameter increased rapidly (being largest at $4-6 \mathrm{~h}$ ). By 2 days post ovulation group I had returned to the pretreatment size. The uteri in group II remained little larger than they were before inoculation (Fig. 3).

Uterine tone increased by $2 \mathrm{~h}$ and highest tonicity occurred at 4-12 $\mathrm{h}$. In the mares that remained infected the increase in uterine tone was slightly delayed as compared to other mares (Fig. 4).

All uterine cultures showed a heavy or moderate (one mare) growth of $\beta$-hemolytic streptococci $6 \mathrm{~h}$ after the inoculation. Two



F i g u r e 2. Cervical relaxation after the bacterial inoculation. Means plotted on the $y$-axis have been calculated from values that were given in the following way: $1=$ tight, $2=$ somewhat relaxed, $3=$ rather well relaxed, $4=$ totally relaxed. Besides averages for group $I(x-x)$ and group II $(\mathrm{O}-. . \mathrm{O})$, the mares from group II that remained infected are shown separately $(0 \ldots .$.$) ).$ 


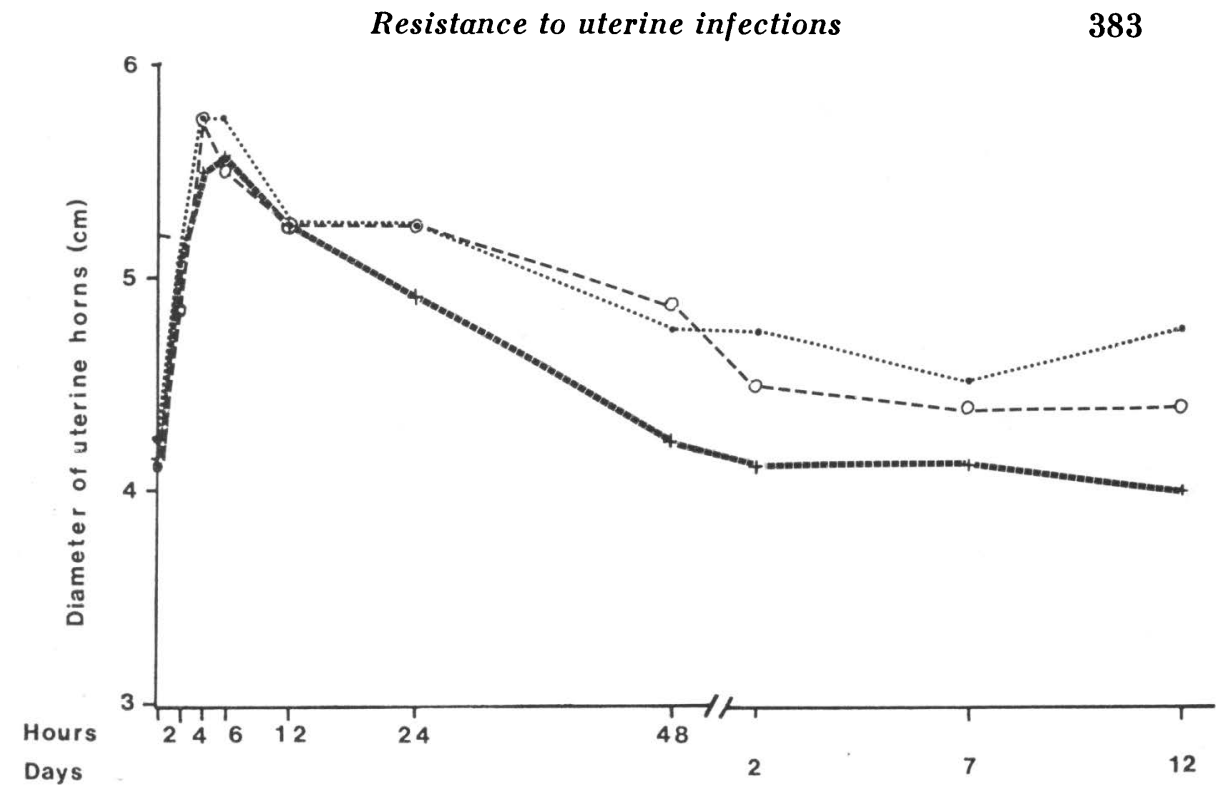

F i g u r e 3. Changes in the diameter of uterine horns $(\mathrm{cm})$ after the bacterial inoculation. Besides averages for group $I(x-x)$ and group II $(O \ldots . .-)^{2}$, the mares from group II that remained infected are shown separately $(0 \ldots . . .0)$.

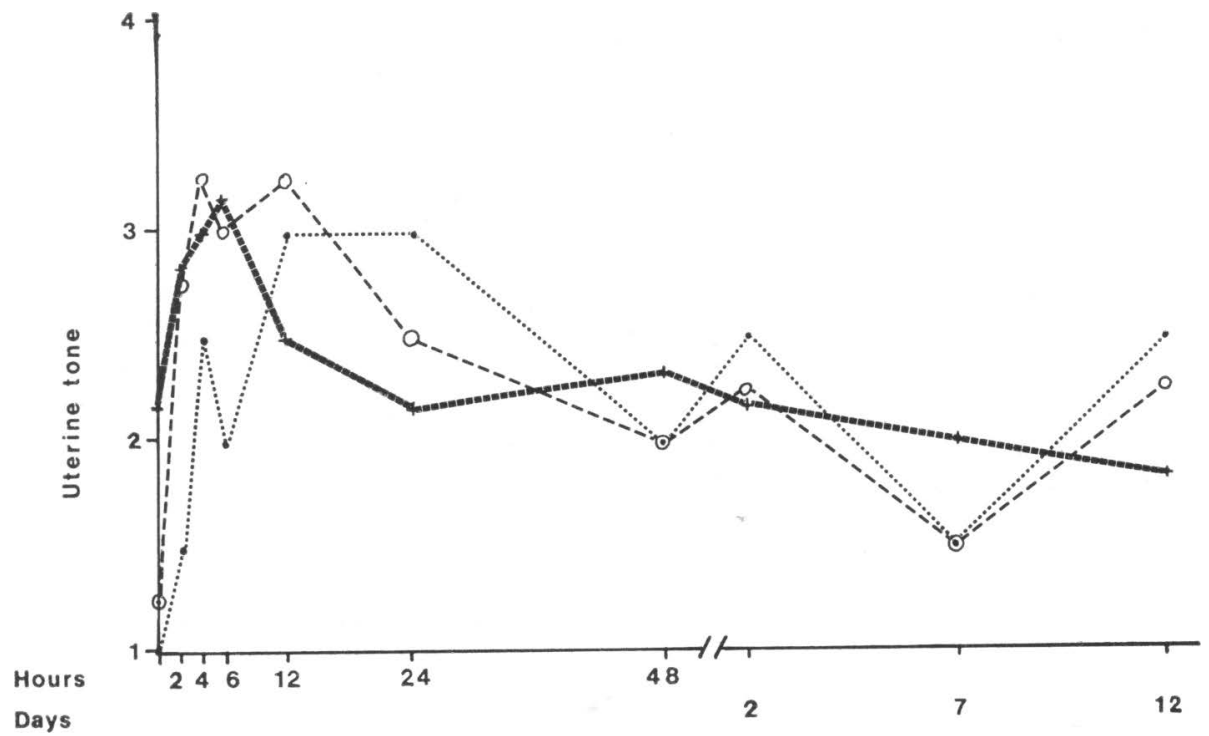

Figure 4. Uterine tone after the bacterial inoculation. Means plotted on the $y$-axis have been calculated from values that were given in the following way: $1=$ flaccid, $2=$ normal, $3=$ increased tone, $4=$ very good tone. Besides averages for group $I(x-x)$ and group II (O-.. O), the mares from group II that remained infected are shown separately $(0 \ldots . . .0)$. 


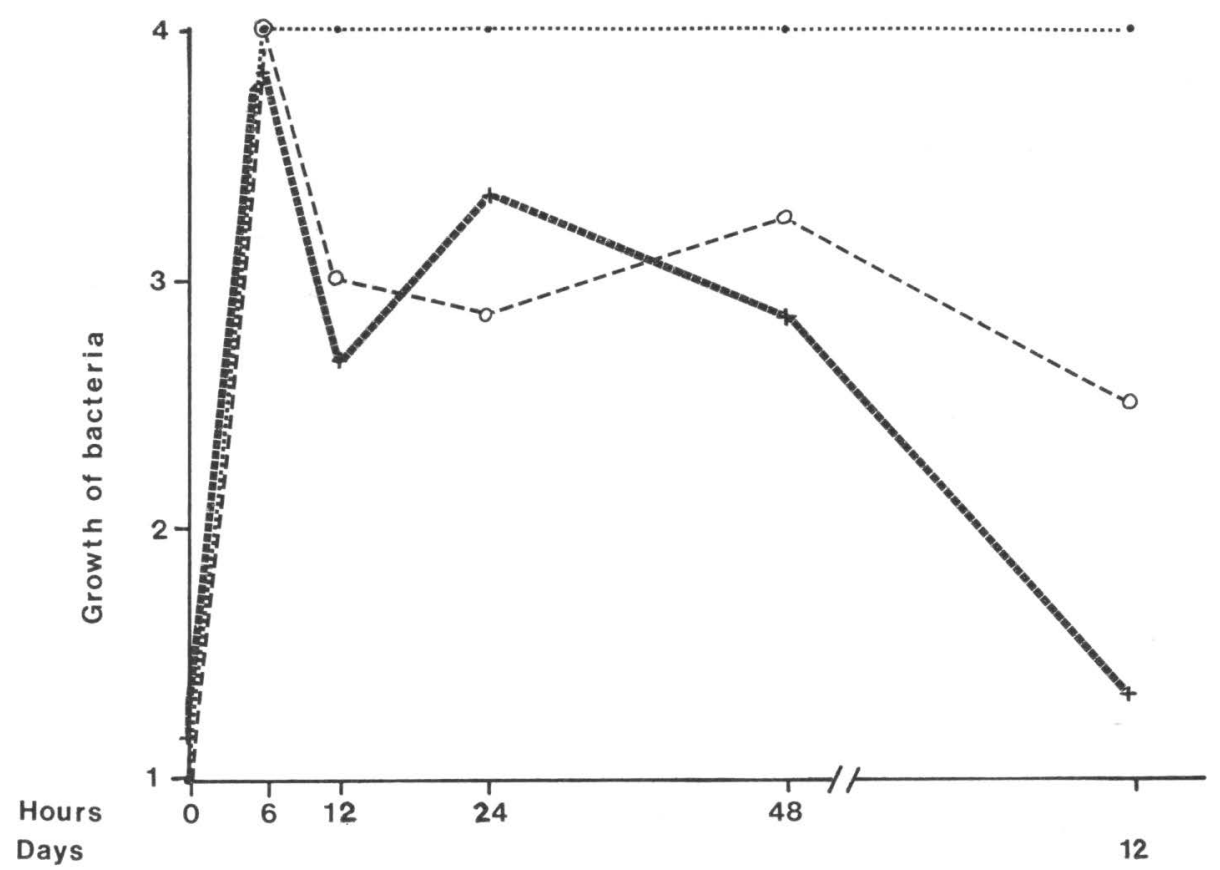

Figure 5. Growth of $\beta$-hemolytic streptococci from uterine swabs after the streptococcal inoculation. Means plotted on the $y$-axis have been calculated from values that were given in the following way: $1=$ no growth, $2=$ light growth $(<10$ colonies $), 3=$ moderate growth (11-100 colonies), $4=$ heavy growth ( $>101$ colonies). Besides averages for group $I(x-x)$ and group II $(O \ldots$.$) , the$ mares from group II that remained infected are shown separately $(\bullet \ldots \bullet)$.

mares from group I had eliminated the infection at $48 \mathrm{~h}$. Two mares from group II had a heavy and one mare from group I had a moderate growth of $\beta$-hemolytic streptococci on the 12th day (Fig. 5).

High numbers of neutrophils were seen in all endometrial smears $6 \mathrm{~h}, 12 \mathrm{~h}$ and $24 \mathrm{~h}$ after the inoculation, but by $48 \mathrm{~h}$ one mare from each group had no more neutrophils.

All mares had a moderate or heavy neutrophil infiltration in biopsy specimens taken $12 \mathrm{~h}$ after the bacterial inoculation. At $48 \mathrm{~h}$ the infiltration varied from mild to heavy. It was strongest in the stratum compactum, but extended all the way through the str. spongiosum. Neutrophils were not seen in myometrium. Four mares (2 from each group) had a mild neutrophil infiltration on day 12 . 
Mononuclear cell infiltration was greatest at $48 \mathrm{~h}$ varying from mild to heavy. One mare from group I had a moderate and 6 mares ( 4 from group $I$ and the 2 permanently infected mares from group II had a mild mononuclear cell infiltration on day 12.

Eosinophils were common at $12 \mathrm{~h}$ and $48 \mathrm{~h}$. Three mares (2 from group I and 1 from group II) had an eosinophil infiltration before bacterial inoculation. Three mares ( 2 from group I and 1 from group II) had no eosinophil infiltration in any of the biopsies. Eosinophils were not found on day 12.

There were no differences between the groups in the number of any type of leukocytes at any particular time. All mares had a large amount of edema in the lamina propria and exudate in the lumen at $12 \mathrm{~h}$ and $48 \mathrm{~h}$ biopsies.

\section{DISCUSSION}

It is clear that mares are well able to eliminate streptococcal infections on their own without treatment. This has very convincingly been shown by Hughes \& Loy (1969), and is supported by the results of this study. Two mares from group II became chronically infected indicating decreased uterine defence.

The overall changes observed in external and vaginal examinations as well as in rectal palpations agree with those reported earlier (Bowman 1972). It is apparent from previous studies that the cervix responds to the streptococcal infection by relaxing rapidly (Hughes \& Loy 1969, Bowman 1972). The results of the above study support this. It should be remembered, however, that the mares were inoculated during estrus, when the cervix is naturally relaxed. The infusion of bacteria and sampling procedures involved passing instruments through the cervix, which may have contributed to the dilation of the cervical canal. In contrast to a previous finding (Hughes \& Loy 1969), also the mares with decreased uterine resistance exhibited a marked cervical relaxation after the inoculation.

The presence of discharge seems to correlate with uterine culture results. Mares with negative cultures of $\beta$-streptococci after the inoculation had no discharge or only a small amount of clear mucus. Mares exhibiting a discharge always showed positive cultures of $\beta$-streptococci, except $1 \mathrm{mare}, 12 \mathrm{~h}$ after infusion. The swab was negative for neutrophils and streptococci in spite of a significant amount of discharge. The $24 \mathrm{~h}$ swab was 
again positive for bacteria and neutrophils. This may be explained by inadequate contact of the swab with the endometrium.

Looking at individual mares, the amount of discharge did not show any correlation with the size of uterine horns. The increase in uterine size was probably due to edema, which was palpable and was also seen in the biopsies. Edema might also be the explanation for increased uterine tone. It is common among practitioners to relate the lack of uterine tone to infections or abnormality. This may be true in cattle, where an increased uterine tone is a characteristic of estrus and a flaccid uterus often accompanies cystic ovaries. In horses, however, one should be aware of the fact that increased uterine tone in a nonpregnant mare might indicate a disease process (Bowman 1972).

Neutrophils were present in such high numbers $6-48 \mathrm{~h}$ after the inoculation that all smears looked almost the same. This is in agreement with a previous study (Peterson et al. 1969).

All biopsies showed a marked neutrophil infiltration 12 and $48 \mathrm{~h}$ after the inoculation. This was accompanied by a mononuclear cell infiltration at $48 \mathrm{~h}$. Neutrophil infiltration should be interpreted as an acute infection, because neutrophils are not normally present in equine endometrial tissue (Kenney 1978).

Eosinophils were frequently encountered in biopsies. Also Peterson et al. (1960) observed eosinophils $6 \mathrm{~h}$ after the bacterial inoculation and the infiltrations persisted even longer. Kenney (1978) stated that eosinophils are found more frequently in inflamed uteri during estrus. It has been assumed that they represent an immunological reaction of an undefined nature (Kenney 1978).

It can be concluded that mares in both groups developed a strong and rapid, but not long-lasting, inflammatory reaction. Two mares from group II were not able to eliminate the infection, but these mares did not differ from other mares in the neutrophil response.

The number of mares in this study was small and that is why very definite conclusions should not be drawn. It seems to be, however, that the failure of compromized mares to eliminate bacteria is not due to a deficient inflammatory response.

\section{REFERENCES}

Asbury, A. C., R. E. W. Halliwell, G. W. Foster \& S. J. Longino: Immunoglobulins in uterine secretions of mares with differing resistance to endometritis. Theriogenology $1980,14,299-308$. 
Bowman, T.: Early response of the equine uterus to induced streptosoccal endometritis. Master's thesis, University of Maryland 1972.

Greenhoff, G. R. \& R. M. Kenney: Evaluation of reproductive status of nonpregnant mares. J. Amer. vet. med. Ass. 1975, 167, 449458.

Hughes, J. P.\& R. G. Loy: Investigations on the effect of intrauterine inoculations of Streptococcus zooepidemicus in the mare. Proc. 15th Ann. Conv. Amer. Ass. Equine Practnrs. 1969, p. 289-292.

Kenney, R. M.: Cyclic and pathologic changes of the mare endometrium as detected by biopsy, with a note on early embryonic death. J. Amer, vet. med. Ass. 1978, 172, 241-261.

Peterson, F. B., R. A. McFeeley \& J. S. E. David: Studies on the pathogenesis of endometritis in the mare. Proc. 15th Ann. Conv. Amer. Ass. Equine Practnrs. 1969, p. 279-287.

Washburn, S. M., O. H. Klesius, V. K. Ganjam \& B. G. Brown: Effect of estrogen and progesterone on the phagocytic response of ovariectomized mares infected in utero with $\beta$-hemolytic streptococci. Amer. J. vet. Res. 1982, 43, 1367-1370.

\section{SAMMANDRAG}

Morfologisk bedömning av akut endometrit hos ston med varierande motståndskraft mot infektioner $i$ livmodern.

Föreliggande undersökning utfördes för att klargöra skillnaden mellan normala ston och ston med patologiska förändringar i endometriet beroende på en inflammatorisk reaktion ansluten till bakteriell infektion. Sex normala ston (biopsi kategori I) och 4 ston med patologiska förändringar i endometriet (biopsi kategori II) inokulerades intrauterint med $\beta$-hämolytiska streptokocker under den andra brunstdagen. Alla ston uppvisade en likadan inflammatorisk reaktion efter den bakteriella inokulationen, vilket konfirmerades vid rektala och vaginala undersökningar. Inga signifikanta skillnader påvisades mellan de två grupperna visavis mängden av flytning, livmoderns tonus och storlek, samt avslapningen av cervix. Leukocytreaktionen, som bestämdes med hjälp av endometriella utstryk och biopsier, var av samma storleksgrad i båda grupperna. Två ston i den patologiska gruppen förmådde inte eliminera infektionen, utan hade vaginal flytning och bakteriologiskt positiva prov från livmodern ända till undersökningens slut. Vår slutsats är, att oförmåga att klara uterina infektioner inte kan förklaras bero på en bristande inflammatorisk reaktion.

(Received May 29, 1986).

Reprints may be requested from: Terttu Katila, EKK, SF-04840 Hautjärvi, Finland. 